Article

\title{
A Cancer Stem Cell Potent Cobalt(III)-Cyclam Complex Bearing Two Tolfenamic Acid Moieties
}

\author{
Paul B. Cressey, Arvin Eskandari and Kogularamanan Suntharalingam * \\ Department of Chemistry, King's College London, London SE1 1DB, UK; paul.cressey@kcl.ac.uk (P.B.C.); \\ arvin.eskandari@kcl.ac.uk (A.E.) \\ * Correspondence: kogularamanan.suntharalingam@kcl.ac.uk; Tel.: +44-207-848-2595
}

Academic Editor: Luigi Messori

Received: 19 December 2016; Accepted: 25 January 2017; Published: 9 February 2017

\begin{abstract}
Cancer stem cells (CSCs) are thought to be responsible for cancer relapse. CSCs are a subtype of cancer cells with the ability to differentiate, self-renew, and form secondary or tertiary tumors. Current cancer treatments-including chemotherapy, radiation, and surgery-effectively remove bulk cancer cells but are unable to eliminate CSCs. Here, we present the synthesis, characterization, and anti-CSC properties of a cobalt(III)-cyclam complex bearing two tolfenamic acid moieties, 3 . Notably, 3 displays sub-micromolar potency towards breast CSCs and bulk breast cancer cells. Detailed mechanistic studies show that 3 is taken up readily by breast CSCs, enters the nucleus, causes DNA damage, and induces caspase-dependent apoptosis. Furthermore, $\mathbf{3}$ inhibits cyclooxygenase-2 (COX-2) expression in CSCs. The mechanism of action of 3 is similar to that of a naproxen-appended cobalt(III)-cyclam complex, $\mathbf{1}$ recently reported by our group. The advantage of 3 over $\mathbf{1}$ is that it has the potential to remove whole tumor populations (bulk cancer cells and CSCs) with a single dose.
\end{abstract}

Keywords: metallopharmaceuticals; cobalt(III)-cyclam complexes; cancer stem cell; nonsteroidal anti-inflammatory drug; DNA damage; COX-2 inhibition

\section{Introduction}

Cancer is the third highest cause of death in the developed world [1]. Despite significant improvements in traditional cancer therapies (chemotherapy, radiation therapy, and surgery), long-term cures for cancers of all tissue types remains out of reach [2]. Tumors have the ability to recur months, if not years, after seemingly effective treatment. Cancer reoccurrence has been heavily linked to the existence of a small subpopulation of tumor cells called cancer stem cells (CSCs) [3,4]. CSCs exhibit cancer and stem-like properties and thus self-renew, divide asymmetrically, and evade standard treatments [5-8]. These traits endow CSCs with the ability to control tumor initiation, propagation, and metastasis $[9,10]$. Given the implications of CSCs, to provide long-lasting durable responses, cancer therapies must have the ability to remove entire tumor populations, including CSCs. Although vulnerabilities in CSC defenses have been identified-such as overactive organelles [11,12], cell surface markers [13-17], dysregulated signaling pathways [18-20], and components of their microenvironment $[21,22]$ - there is still no clinically approved agent (chemical or biological) that can effectively remove CSCs. The development of CSC-potent agents is in its infancy, and most of the drug candidates undergoing preclinical or clinical trials are completely organic in nature [7]. Our group and others have recently shown that metal complexes are capable of potently and selectively killing CSCs (over bulk cancer cells) [23-28].

CSC depletion can be achieved by disrupting the microenvironments maintaining and supporting CSCs [21,22]. The CSC microenvironment is believed to be hypoxic, and the hypoxia-inducible factors (HIFs), HIF1 $\alpha$ and HIF2 $\alpha$, are thought to be involved in CSC-associated self-renewal and 
metastasis [29-33]. Specifically, HIF1 $\alpha$ has been shown to promote CSC mammosphere growth under hypoxic conditions [34]. Therefore, prodrugs capable of undergoing activation in hypoxic conditions can potentially block CSC growth. Octahedral cobalt(III) complexes containing cytotoxic ligands can be utilized for this purpose, as the oxidized form is inert, but upon one-electron reduction to the labile $\mathrm{Co}$ (II) form, the coordinated cytotoxic ligands can be released [35-37]. A number of Co(III) complexes containing tetradentate nitrogen ligands such as cyclam (1,4,8,11-tetraazacyclotetradecane), cyclen (1,4,7,10-tetraazacyclododecane), and TPA (tris(2-pyridylmethyl)amine), have been used to deliver therapeutic and imaging agents to hypoxic tumor microenvironments [38-42]. The reduction potential of these complexes range from 0 to $-1400 \mathrm{mV}$ (vs normal hydrogen electrode, NHE), therefore, in theory they can be fine-tuned by ligand modification to coincide with the CSC microenvironment.

We previously reported the anti-CSC properties of a cobalt(III)-cyclam complex, 1 (Figure 1), containing naproxen, a nonsteroidal anti-inflammatory drug (NSAID). This complex was shown to release naproxen under reducing conditions and selectively kill CSCs grown under hypoxic-mimicking conditions [24]. The mechanism of action of 1 involves genomic DNA damage and cyclooxygenase-2 (COX-2) inhibition. NSAIDs, like naproxen, inhibit cyclooxygenase (COX-1 or COX-2)-catalyzed production of prostaglandin, a mediator of inflammation [43]. The inducible isoform, COX-2, is overexpressed in colon, glioma, and breast cancer CSCs and promotes their proliferation, and therefore is a viable a target for CSC therapy [44-46]. Here, we report a novel tolfenamic acid-appended cobalt(III)-cyclam complex, 3, capable of potently killing breast CSCs and bulk breast cancer cells in vitro. The rationale for the attachment of tolfenamic acid to the cobalt(III)-cyclam core is two-fold; it increases the lipophilicity of the complex, which facilitates cell uptake, and it inhibits COX-2 [47], which is overexpressed in breast CSCs. The CSC cytotoxicity and mechanism of action of $\mathbf{3}$ will be discussed in detail, and compared to 1 .

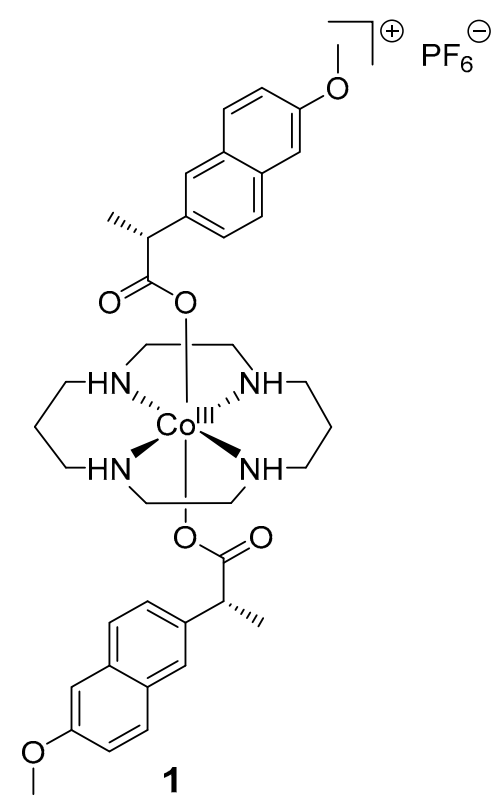

Figure 1. Chemical structure of a cobalt(III)-cyclam complex bearing two naproxen molecules, 1, which was previously reported to selectively kill breast cancer stem cells (CSCs) over bulk breast cancer cells.

It should be noted that several metal-NSAIDs have been previously reported, and their binding to biomolecules such as DNA and human serum albumin (HSA) has been well characterized using spectroscopic methods [48-52]. In general, metal-NSAID complexes display stronger binding to biomolecules than the corresponding free NSAID. Many of the metal-NSAID complexes display anti-inflammatory/analgesic, antibacterial, and antiproliferative properties [53]. Encouragingly, some metal-NSAID complexes exhibit greater cytotoxicity than cisplatin. A recent comprehensive review 
concluded that the molecular weight of metal-NSAID complexes (with the same NSAID) was linearly correlated to their antiproliferative activity against breast cancer cells (MCF-7) [53]. We recently reported a series of copper(II)-phenanthroline-indomethacin complexes capable of selectively killing breast CSCs over bulk breast cancer cells [23,25]. Our studies have shown that metal-NSAID complexes are an important class of anti-CSC agents that deserves further investigation.

\section{Results and Discussion}

The novel cobalt(III)-cyclam complex, 3 (Scheme 1), was synthesized by reacting trans-dichloro(cyclam)-cobalt(III) chloride, 2, with tolfenamic acid (2.5 equivalents) in methanol (dried over $\mathrm{Na}_{2} \mathrm{SO}_{4}$ ) in the presence of excess silver(I) oxide (4.5 equivalents). After precipitation of the crude product using diethyl ether and conversion to the corresponding hexafluorophosphate salt, alumina column chromatography (dichloromethane (DCM):methanol (95:5)) was preformed to isolate 3 as a pure light-brown solid, in a reasonable yield (34\%). Complex 3 was characterized by ${ }^{1} \mathrm{H}$ and ${ }^{13} \mathrm{C}$ NMR, infrared spectroscopy, high-resolution electrospray ionization (ESI)-TOF mass spectrometry, and elemental analysis (Figures S1-S3 in the Supplementary Materials). Attachment of tolfenamic acid to cobalt(III)-cyclam via the carboxylic acid group was confirmed by the disappearance of the hydroxyl signal (at 13.15 ppm, Figure S4) in the ${ }^{1} \mathrm{H}$ NMR spectrum of 3 . Furthermore, the aromatic proton signals shifted (up to $0.4 \mathrm{ppm}$ ) relative to tolfenamic acid, indicative of metal coordination. A distinctive molecular ion peak with the appropriate isotopic pattern expected for 3 was observed in the ESI mass spectrum $\left(m / z=779.2305 \mathrm{amu},\left[\mathrm{M}-\mathrm{PF}_{6}\right]^{+}\right)$, providing further evidence for product formation. The purity of $\mathbf{3}$ was established by elemental analysis.

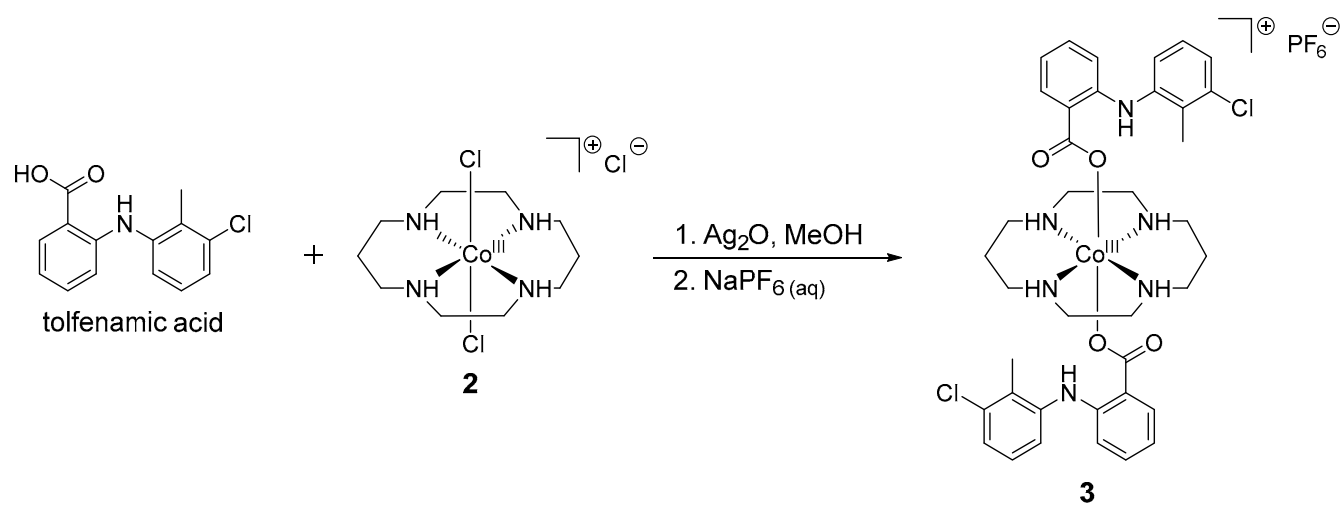

Scheme 1. The reaction scheme for the preparation of the novel cobalt(III)-cyclam complex, 3, from trans-dichloro(cyclam)-cobalt(III) chloride, 2, and tolfenamic acid.

Given that the analogous cobalt(III)-cyclam-naproxen complex, 1, and other cobalt complexes bearing tetradentate ligands have been reported to effectively cleave DNA [24], the DNA nuclease activity of 3 was investigated by agarose gel electrophoresis. Upon incubation of plasmid pUC19 DNA (100 ng) with $3(0-20 \mu \mathrm{M}$ for $20 \mathrm{~h}$ in the absence of external reducing agents), a marked increase in the amount of nicked circular DNA and a concurrent decrease in the in the amount of supercoiled DNA was observed, indicative of DNA cleavage (Figure 2A). In the presence of cellular reductants, ascorbic acid, and glutathione (10-fold excess), the nuclease activity of 3 was markedly enhanced (Figure 2B,C). In the presence of ascorbic acid, supercoiled pUC19 DNA was completely converted to circular DNA (at $5 \mu \mathrm{M}$ ), whereas in the presence of glutathione, the DNA was cleaved into several fragments (at $2 \mu \mathrm{M}$ ). This suggests that 3-mediated DNA cleavage is redox-dependent. To determine the oxidative mechanism by which 3 induces DNA cleavage, nuclease activity was probed in the presence of reactive oxygen species (ROS) scavengers (DMSO, $t \mathrm{BuOH}, \mathrm{KI}$, and $\mathrm{NaN}_{3}$ ) (Figure $2 \mathrm{D}$ ). $\mathrm{KI}$ and $\mathrm{NaN}_{3}$ displayed the greatest inhibitory effect, suggesting that hydrogen peroxide and singlet oxygen are the major ROS intermediates formed during the DNA cleavage process. A similar result was previously observed for 
1 [24]. $t \mathrm{BuOH}$ partially inhibited 3 -induced cleavage, therefore, hydroxyl radicals could also play a role in the nuclease activity of $\mathbf{3}$. To gain insight into the DNA-binding mode of 3 prior to initiating DNA cleavage, nuclease activity was examined in the presence of a major groove binder (methyl green, $50 \mu \mathrm{M}$ ) and a minor groove binder (DAPI, 2-(4-amidinophenyl)-1H-indole-6-carboxamidine, $50 \mu \mathrm{M})$. Cleavage was found to be considerably reduced in the presence of both methyl green and DAPI, suggesting that 3 binds to both the minor and major DNA grooves (Figure 2E).

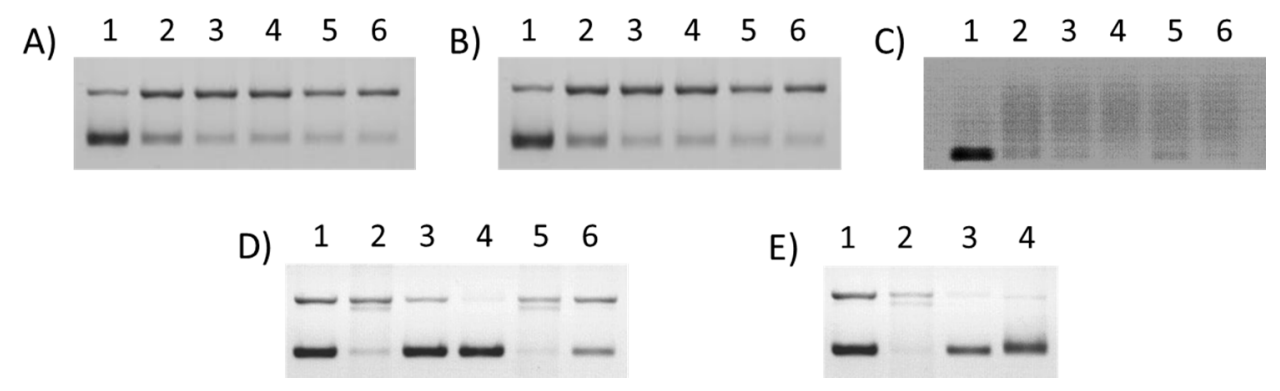

Figure 2. (A) Concentration-dependent DNA cleavage by 3 after $20 \mathrm{~h}$ incubation. Lane 1: DNA only; Lanes 2-6: DNA $+2,5,10,15$, and $20 \mu \mathrm{M}$ of 3. (B) Effect of ascorbic acid on 3-mediated DNA cleavage after $20 \mathrm{~h}$ incubation. Lane 1: DNA only; Lanes 2-6: DNA $+2,5,10,15$, and $20 \mu \mathrm{M}$ of 3 with 10 equivalents of ascorbic acid. (C) Effect of glutathione on 3-mediated DNA cleavage after $20 \mathrm{~h}$ incubation. Lane 1: DNA only; Lanes 2-6: DNA $+2,5,10,15$, and $20 \mu \mathrm{M}$ of 3 with 10 equivalents of glutathione. (D) Inhibition of 3-mediated DNA cleavage by reactive oxygen species (ROS) scavengers after $20 \mathrm{~h}$ incubation. Lane 1: DNA only; Lane 2: DNA + $3(10 \mu \mathrm{M})$; Lanes 3-6: DNA + $3(10 \mu \mathrm{M})+$ $\mathrm{NaN}_{3}(40 \mathrm{mM}), \mathrm{KI}(40 \mathrm{mM}), \mathrm{DMSO}(10 \mathrm{mM})$, or $\mathrm{tBuOH}(10 \mathrm{mM})$. (E) Inhibition of 3-mediated DNA cleavage by DNA minor and major groove binders after $20 \mathrm{~h}$ incubation. Lane 1: DNA only; Lane 2: DNA + $3(10 \mu \mathrm{M})$; Lane 3: DNA + $3(10 \mu \mathrm{M})+$ methyl green $(50 \mu \mathrm{M})$; Lane 4: DNA + $3(10 \mu \mathrm{M})+$ DAPI $(50 \mu \mathrm{M})$.

The lipophilicity of $\mathbf{3}$ was determined by measuring the extent to which it partitioned between octanol and water $(\mathrm{P})$ using the shake-flask method. The $\log \mathrm{P}$ value for 3 was calculated to be $0.96 \pm 0.05$, which is indicative of hydrophobicity. The hydrophobic character of 3 suggests that the complex should be readily internalized by cells. UV-visible spectroscopy and high-resolution ESI-TOF MS studies were carried out to assess the stability of $\mathbf{3}$ in biologically relevant solutions. In phosphate-buffered saline (PBS), the absorption associated to $3(25 \mu \mathrm{M})$ decreased steadily over the course of $24 \mathrm{~h}$ at $37^{\circ} \mathrm{C}$ (Figure S5). In contrast, 1 displayed no significant spectral changes under the same conditions [24]. Upon addition of ascorbic acid $(250 \mu \mathrm{M})$ to $3(25 \mu \mathrm{M})$ in PBS, a marked change in the UV-visible trace was observed, followed by a decrease in absorption over the course of $24 \mathrm{~h}$, yielding a spectrum similar to free tolfenamic acid (Figures S6 and S7). This suggests that tolfenamic acid is released from 3 under these conditions. Upon incubating $3(25 \mu \mathrm{M})$ with glutathione $(250 \mu \mathrm{M})$ in PBS for $72 \mathrm{~h}$, the ESI-TOF MS (positive mode) displayed new peaks corresponding to [tolfenamic acid] $^{+}(260.9963 \mathrm{~m} / \mathrm{z})$ and [tolfenamic acid $\left.+\mathrm{K}\right]^{+}(300.9819 \mathrm{~m} / \mathrm{z})$ (Figure S8). This shows that tolfenamic acid is liberated, presumably through reduction of the cobalt metal center from $\mathrm{Co}^{\mathrm{III}}$ to $\mathrm{CO}^{\mathrm{II}}$. The presence of a peak corresponding to the oxidized form of glutathione, [GSSG $\left.+\mathrm{H}\right]^{+}(613.1581$ $\mathrm{m} / \mathrm{z}$ ) and the absence of a peak for the reduced form, implies that 3 has been reduced (Figure S8).

The cytotoxicity of 3 towards bulk breast cancer cells (HMLER) and breast CSCs (HMLER-shEcad) was assessed using the colorimetric MTT (3-(4,5-dimethylthiazol-2-yl)-2,5-diphenyltetrazolium bromide) assay. $\mathrm{IC}_{50}$ values, the concentration required to decrease cell viability by $50 \%$, were calculated from dose-response curves (Figure S9) and are summarized in Table 1. The cobalt(III)-cyclam complex, 3, exhibited sub-micromolar potency towards HMLER and HMLER-shEcad cells, comparable to $\mathbf{1}$. Interestingly, $\mathbf{3}$ kills CSCs and bulk cancer cells indiscriminately, whereas $\mathbf{1}$ displays 4 -fold selective potency for CSCs over bulk cancer cells. Therefore, 3 has the potential to remove cancer cell 
populations in their entirety (bulk cancer cells and CSCs) with a single dose. Notably, the $\mathrm{IC}_{50}$ value of 3 for HMLER-shEcad cells was 24-fold lower than that of salinomycin, a well-established CSC toxin, and similar to a series of CSC-selective copper(II)-phenanthroline-NSAID complexes recently reported by our group $[23,25]$. We have previously shown that tolfenamic acid displays moderate toxicity towards HMLER and HMLER-shEcad cells (Table 1) [25]. The data acquired in this study shows that the cytotoxicity of tolfenamic acid toward CSCs and bulk cancer cells is significantly enhanced by tethering it to cobalt(III)-cyclam. Given the stability studies above (UV-visible spectroscopy and high-resolution ESI-TOF MS), the CSC cytotoxicity of 3 is likely to result from its reduced products rather than intact 3 .

Table 1. IC 50 values of 1, 3, tolfenamic acid, and salinomycin against HMLER and HMLER-shEcad cells and HMLER-shEcad mammospheres determined after 72 or $120 \mathrm{~h}$ incubation (mean of three independent experiments $\pm \mathrm{SD}$ ). The $\mathrm{IC}_{50}$ values correspond to the concentration required to decrease cell or mammosphere viability by $50 \%$ and were calculated from dose-response curves.

\begin{tabular}{cccc}
\hline Compound & $\begin{array}{c}\text { HMLER } \\
\mathbf{I C}_{\mathbf{5 0}}(\boldsymbol{\mu M})\end{array}$ & $\begin{array}{c}\text { HMLER-shEcad } \\
\mathbf{I C}_{\mathbf{5 0}}(\boldsymbol{\mu M})\end{array}$ & $\begin{array}{c}\text { Mammosphere } \\
\mathbf{I C}_{\mathbf{5 0}}(\boldsymbol{\mu M})\end{array}$ \\
\hline $\mathbf{1}^{1}$ & $0.43 \pm 0.05$ & $0.11 \pm 0.03$ & $0.98 \pm 0.02$ \\
$\mathbf{3}$ & $0.22 \pm 0.01$ & $0.21 \pm 0.01$ & $1.83 \pm 0.28$ \\
salinomycin $^{1}$ & $12.17 \pm 3.16$ & $5.06 \pm 1.45$ & $14.05 \pm 1.58$ \\
tolfenamic acid $^{2}$ & $30.77 \pm 4.69$ & $57.95 \pm 1.62$ & $>66$ \\
\hline \multicolumn{4}{c}{}
\end{tabular}

When cultured in serum-free, anchorage-independent conditions, breast CSCs can form three-dimensional, tumor-like structures called mammospheres [54]. The ability of 3 to inhibit the formation of mammospheres from single-cell suspensions of HMLER-shEcad cells was determined using an inverted microscope. Dosage with 3 (at the $\mathrm{IC}_{20}$ value after 5 days of incubation) reduced the number of mammospheres formed by $44 \%$ (Figure 3A). The size of mammospheres formed was also markedly reduced upon incubation with 3 (Figure 3B). A similar effect was previously noted for 1 and salinomycin [24,25]. Treatment with tolfenamic acid (at $20 \mu \mathrm{M}$ after 5 days of incubation) did not noticeably alter the number or size of mammospheres formed (Figure 3A,B). To determine the ability of 3 to reduce mammosphere viability, the colorimetric resazurin-based reagent, TOX8, was employed. The $\mathrm{IC}_{50}$ values, the concentration required to decrease mammosphere viability by 50\%, were extrapolated from dose-response curves (Figure 3C) and are summarized in Table 1. The cobalt(III)-cyclam complex, 3, displayed micromolar mammosphere potency, comparable to 1 and 8-fold better than salinomycin. Tolfenamic acid is relatively nontoxic against mammospheres $\left(\mathrm{IC}_{50}>66 \mu \mathrm{M}\right)$. Hypoxic conditions are known to enhance mammosphere growth from single-cell HMLER suspensions in a HIF1 $\alpha$-dependent manner. The mammosphere potency of 3 in the presence of cobalt chloride $(5 \mu \mathrm{M})$, a hypoxia-mimicking agent that activates HIF1 $\alpha$, was unaltered (Figure S10). In the presence of cobalt chloride $(5 \mu \mathrm{M}), 3$ (at the $\mathrm{IC}_{20}$ value after 5 days of incubation) considerably reduced the number and size of mammospheres formed (Figures S11 and S12). A similar result was observed for 1-treatment [24]. Taken together, this shows that 3 is able to reduce the formation, growth, and viability of CSCs grown in normoxic and hypoxic-like conditions equally. 

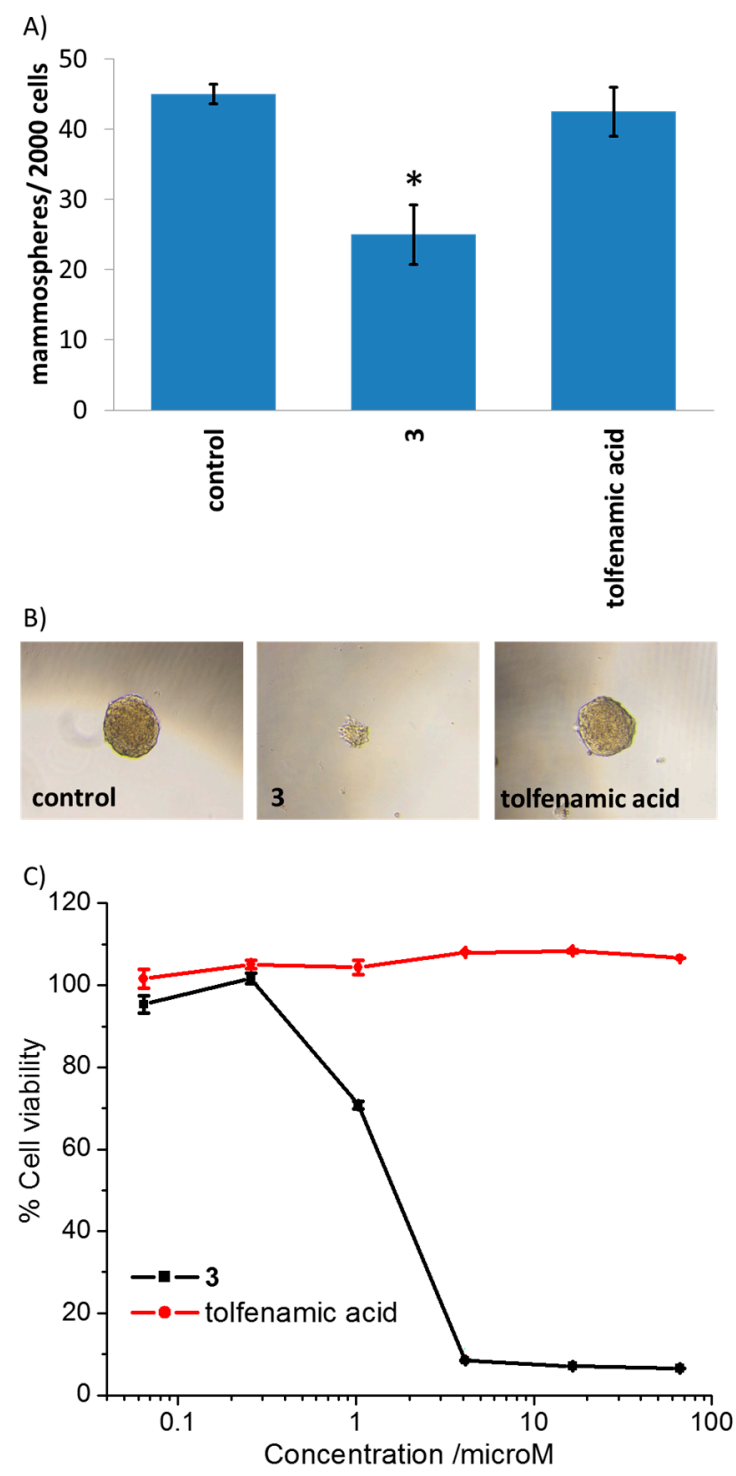

Figure 3. (A) Quantification of mammosphere formation with HMLER-shEcad cells untreated and treated with 3 or tolfenamic acid (at their $\mathrm{IC}_{20}$ values, 5 days). Error bars represent standard deviations and Student's $t$-test, ${ }^{*} p<0.05$. (B) Representative bright-field images $(\times 10)$ of HMLER-shEcad mammospheres in the absence and presence of 3 or tolfenamic acid (at their $\mathrm{IC}_{20}$ values, 5 days). (C) Representative dose-response curves for the treatment of HMLER-shEcad mammospheres with 3 or tolfenamic acid after 5 days of incubation.

Cellular uptake studies were carried to determine the cell permeability and intracellular localization of 3. HMLER-shEcad cells were incubated with $3(0.5 \mu \mathrm{M}$ for $16 \mathrm{~h})$ and the cobalt content was determined in the whole cell and cytoplasmic, nuclear, and membrane fractions by inductively coupled plasma mass spectrometry (ICP-MS). As depicted in Figure 4A, 3 is readily internalized by HMLER-shEcad cells (149.5 ppb of Co/million cells). The whole cell uptake of 3 is 2-fold lower than $\mathbf{1}$ [24], which may explain the higher potency of the latter against HMLER-shEcad cells (Table 1). A reasonable amount of 3 was detected in the nucleus $(11.4 \mathrm{ppb}$ of $\mathrm{Co} / \mathrm{million}$ cells), giving it access to genomic DNA. Therefore, 3 could induce its cytotoxic effect by genomic DNA damage. It should be noted that a large proportion of internalized 3 was also detected in the cytoplasm (65.2 $\mathrm{ppb}$ of $\mathrm{Co} /$ million cells), suggesting that cellular toxicity could also result from genomic DNA-independent mechanisms. 

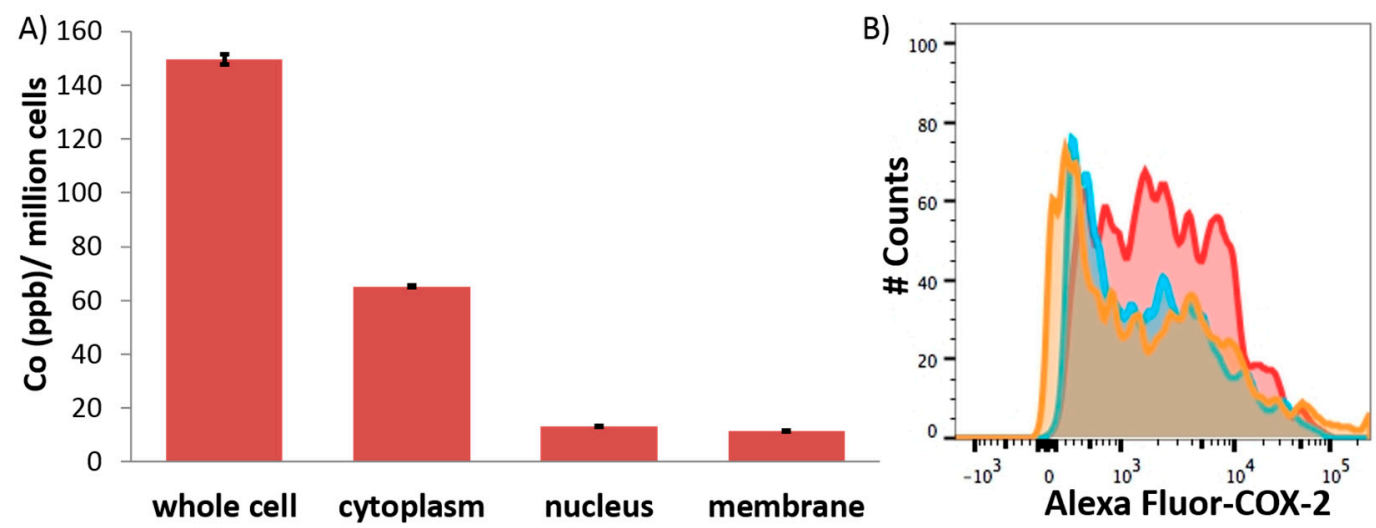

Figure 4. (A) Cobalt content in whole cell, cytoplasm, nucleus, and membrane fractions isolated from HMLER-shEcad cells treated with $3(0.5 \mu \mathrm{M}$ for $16 \mathrm{~h})$. (B) Representative histograms displaying the green fluorescence emitted by anti-COX-2 (cyclooxygenase-2) Alexa Fluor $488 \mathrm{~nm}$ antibody-stained HMLER-shEcad cells treated with lipopolysaccharide (LPS) ( $5 \mu \mathrm{M}$ for $24 \mathrm{~h}$ ) (red) followed by $48 \mathrm{~h}$ in media containing $1(0.125 \mu \mathrm{M}$ : blue and $0.5 \mu \mathrm{M}$ : orange).

As 3 was found to enter the nucleus and exhibit high nuclease activity in cell-free systems, immunoblotting studies were conducted to determine if the genomic DNA damage pathway was activated. HMLER-shEcad cells treated with $3(0.125-0.5 \mu \mathrm{M}$ for $72 \mathrm{~h})$ displayed a marked increase in the expression of phosphorylated $\mathrm{H} 2 \mathrm{AX}(\gamma \mathrm{H} 2 \mathrm{AX})$ and a slight increase in the expression of phosphorylated CHK2 (Figure S13), suggestive of DNA damage. An increase in $\gamma \mathrm{H} 2 \mathrm{AX}$ and phosphorylated-CHK2 expression was also observed for 2-treatment ( $20 \mu \mathrm{M}$ for $72 \mathrm{~h})$. DNA damage, when left unrepaired, can lead to apoptosis [55], therefore, the expression of proteins associated to apoptosis were monitored. HMLER-shEcad cells dosed with $3(0.5 \mu \mathrm{M}$ for $72 \mathrm{~h})$ exhibited a clear increase in the level of cleaved caspase 3 and 7 compared to untreated control cells, indicative of caspase-dependent apoptosis (Figure S13). Notably, 2- or tolfenamic acid-treatment (both $20 \mu \mathrm{M}$ for $72 \mathrm{~h}$ ) did not trigger caspase 3 or 7 cleavage (Figure S13). Collectively, the immunoblotting studies show that 3 induces genomic DNA damage and apoptotic CSC death. A similar result was also observed for 1-treatment [24], implying that both compounds evoke similar cellular responses regardless of their varying potencies.

COX-2 expression has been implicated in CSC proliferation and CSC-assisted metastasis $[45,56,57]$. As 3 possesses two tolfenamic acid molecules, which are well-known COX-2 inhibitors, flow cytometric studies were conducted to determine if the mechanism of action of 3 involved COX-2 inhibition. HMLER-shEcad cells pretreated with lipopolysaccharide (LPS) $(5 \mu \mathrm{M}$ for $24 \mathrm{~h})$, to increase basal COX-2 levels, and dosed with $3(0.125 \mu \mathrm{M}$ and $0.5 \mu \mathrm{M}$ for $48 \mathrm{~h})$ displayed a noticeable decrease in COX-2 expression (Figure 4B). This suggests that the cytotoxic effect of 3 may involve COX-2 downregulation.

In summary, we report a cobalt(III)-cyclam complex, 3, that is able to release tolfenamic acid under reducing conditions. The reduced forms of 3 are likely to be responsible for the biological activity observed. The cobalt(III)-cyclam complex, 3, kills bulk breast cancer cells and breast CSCs with sub-micromolar toxicity, and potently inhibits mammosphere formation in normoxic and hypoxic-like conditions. The biophysical and cellular properties observed for $\mathbf{3}$ are similar, but distinct, to those of $\mathbf{1}$, a naproxen-appended cobalt(III)-cyclam complex previously reported by our group. As 3 displays equal potency towards bulk cancer cells and CSCs (unlike 1), it could potentially be used to remove entire cancer populations with a single dose. This study not only shows that cobalt(III) complexes with tetradentate ligands and NSAIDs warrant further investigation as anticancer agents, but it also provides insight into cobalt-induced cell death. 


\section{Materials and Methods}

\subsection{General Procedures}

All synthetic procedures were performed under normal atmospheric conditions. ${ }^{1} \mathrm{H}$ and ${ }^{13} \mathrm{C}$ NMR spectra were recorded on a BrukerAvance $400 \mathrm{MHz}$ Ultrashield NMR spectrometer (Billerica, MA, USA). High-resolution time-of-flight electron spray ionization mass spectra were recorded on a BrukerDaltronics Esquire 3000 spectrometer (Bremen, Germany) by Dr. Lisa Haigh (Imperial College London). Fourier-transform infrared (FTIR) spectra were recorded with an IRAffinity-1S Shimadzu spectrophotometer (Shimadzu, Japan). Elemental analysis was performed commercially by Stephen Boyer (London Metropolitan University). trans-Dichloro(cyclam)-cobalt(III) chloride, 2, was prepared according to a previously reported protocol [58].

\subsection{Synthesis of $\operatorname{Co}(1,4,8,11$-Tetraazacyclotetradecane)(Tolfenamic Acid) 2 (3)}

Tolfenamic acid (104 mg, $0.4 \mathrm{mmol})$ was dissolved in $\mathrm{MeOH}(45 \mathrm{~mL})$ dried with $\mathrm{Na}_{2} \mathrm{SO}_{4} .2(60 \mathrm{mg}$, $0.16 \mathrm{mmol})$ in $\mathrm{MeOH}(5 \mathrm{~mL})$, and $\mathrm{Ag}_{2} \mathrm{O}(165 \mathrm{mg}, 0.72 \mathrm{mmol})$ was added to this solution and the mixture was stirred for 3 days. The resulting silver salts were removed by filtration and the volume of the filtrate was reduced to $\sim 5 \mathrm{~mL}$. Diethyl ether $(100 \mathrm{~mL})$ was added and the resulting precipitate was collected and washed with diethyl ether $(20 \mathrm{~mL})$. The crude product was dissolved in acetone, filtered, and the filtrate dispersed in a solution of $\mathrm{NaPF}_{6}(151 \mathrm{mg}, 0.9 \mathrm{mmol})$ in water $(10 \mathrm{~mL})$. The resulting suspension was left overnight and the precipitate collected and washed with water $(2 \times 10 \mathrm{~mL})$. The crude product was further purified by $\mathrm{Al}_{2} \mathrm{O}_{3}$ column chromatography (DCM:MeOH (95:5)) to yield 3 as a light-brown solid (50 mg, $0.05 \mathrm{mmol}, 34 \%$ ); mp. $227.0-227.5{ }^{\circ} \mathrm{C} ;{ }^{1} \mathrm{H}$ NMR $(400 \mathrm{MHz}, \mathrm{DMSO}) \delta$ $9.83(\mathrm{~s}, 2 \mathrm{H}), 8.40(\mathrm{~s}, 4 \mathrm{H}), 7.50(\mathrm{dd}, 2 \mathrm{H}), 7.30-7.14(\mathrm{~m}, 8 \mathrm{H}), 6.86(\mathrm{~d}, 2 \mathrm{H}), 6.74(\mathrm{t}, 2 \mathrm{H}), 3.07-2.55(\mathrm{~m}, 14 \mathrm{H})$, 2.48-2.31 (m, 4H), 2.29 (s, 6H), 2.28-2.20 (m, 2H); IR (solid, $\mathrm{cm}^{-1}$ ) 3261, 3091, 2888, 1613, 1580, 1560, 1501, 1464, 1353, 1277, 1249, 1154, 1105, 1073, 1041, 1009, 832, 773, 747, 692, 974, 614, 556; ESI-MS Calcd. for $\mathrm{C}_{38} \mathrm{H}_{46} \mathrm{Cl}_{2} \mathrm{CoN}_{6} \mathrm{O}_{4}\left[\mathrm{M}-\mathrm{PF}_{6}\right]^{+}: 780.1964$ amu. Found $\left[\mathrm{M}-\mathrm{PF}_{6}\right]^{+}:$779.2305 amu.; Anal. Calcd. for $\mathrm{C}_{38} \mathrm{H}_{46} \mathrm{Cl}_{2} \mathrm{CoN}_{6} \mathrm{O}_{4} \mathrm{PF}_{6}: \mathrm{C}, 49.31 ; \mathrm{H}, 5.01 ; \mathrm{N}, 9.08$. Found: C, 49.34; H, 5.13; N, 8.97.

\subsection{DNA Cleavage Studies}

Plasmid DNA (pUC19) was purchased from Invitrogen (Carlsbad, CA, USA). The DNA cleavage activity of 3 was determined by monitoring the conversion of supercoiled plasmid DNA (form I) to nicked circular DNA (form II) in Tris- $\mathrm{HCl}$ buffer ( $5 \mathrm{mM}, \mathrm{pH} 7.4)$, using agarose-gel electrophoresis. To probe the effect of compound concentration on cleavage, solutions containing DNA (100 ng) and 3 $(0-20 \mu \mathrm{M})$, with a total reaction volume of $20 \mu \mathrm{L}$, were incubated at $37^{\circ} \mathrm{C}$ for $20 \mathrm{~h}$. To determine the oxidative cleavage mechanism, solutions containing DNA (100 ng), $3(10 \mu \mathrm{M})$, and various radical scavenges ( 10 or $40 \mathrm{mM}$ of $\mathrm{KI}, \mathrm{DMSO}, t \mathrm{BuOH}$, and $\mathrm{NaN}_{3}$ ), with a total reaction volume of $20 \mu \mathrm{L}$, were incubated at $37^{\circ} \mathrm{C}$ for $20 \mathrm{~h}$. Reactions were also conducted in the presence of 10 equivalents of ascorbic acid or glutathione, and in the presence of methyl green $(50 \mu \mathrm{M})$ and DAPI $(50 \mu \mathrm{M})$. After incubation, loading buffer ( $5 \mu \mathrm{L}$, containing $0.25 \%$ bromophenol blue, $0.25 \%$ xylene cyanol, and $60 \%$ glycerol) was added and reaction mixtures were immediately loaded onto a 1\% agarose gel containing ethidium bromide $\left(1.0 \mathrm{mg} \cdot \mathrm{mL}^{-1}\right)$. The DNA fragments were separated by applying $60 \mathrm{~V}$ for $2 \mathrm{~h}$ in Tris-acetate EDTA (TAE) buffer. The DNA bands were analyzed under UV light using a Fujifilm Image Reader LAS-3000 (Tokyo, Japan).

\subsection{Measurement of Water-Octanol Partition Coefficient $(\log P)$}

The LogP value of 3 was determined using the shake-flask method and UV-vis spectroscopy (Agilent Cary 100 UV-vis spectrophotometer, Santa Clara, CA, USA). The octanol used in this experiment was presaturated with water. An aqueous solution of $3(500 \mu \mathrm{L}, 100 \mu \mathrm{M})$ was incubated with octanol $(500 \mu \mathrm{L})$ in a $1.5 \mathrm{~mL}$ tube. The tube was shaken at room temperature for $24 \mathrm{~h}$. The 
two phases were separated by centrifugation and 3 content in each phase was determined by UV-vis spectroscopy.

\subsection{Cell Lines and Cell Culture Conditions}

The human mammary epithelial cell lines, HMLER and HMLER-shEcad, were kindly donated by R. A. Weinberg (Whitehead Institute, MIT) [59]. HMLER and HMLER-shEcad cells were maintained in Mammary Epithelial Cell Growth Medium (MEGM) with supplements and growth factors (bovine pituitary extract (BPE), hydrocortisone, human epidermal growth factor (hEGF), insulin, and gentamicin/amphotericin-B). The cells were grown at $310 \mathrm{~K}$ in a humidified atmosphere containing $5 \% \mathrm{CO}_{2}$.

\subsection{Cytotoxicity MTT Assay}

The colorimetric MTT assay was used to determine the toxicity of 3. HMLER or HMLER-shEcad cells $\left(5 \times 10^{3}\right)$ were seeded in each well of a 96-well plate. After incubating the cells overnight, various concentrations of $3(0.0004-100 \mu \mathrm{M})$, were added and incubated for $72 \mathrm{~h}$ (total volume $200 \mu \mathrm{L}$ ). A stock solution of 3 was prepared in DMSO $(10 \mathrm{mM})$ and diluted using media. The final concentration of DMSO in each well was $0.5 \%$, and this amount was present in the untreated control. After $72 \mathrm{~h}$, the medium was removed, $200 \mu \mathrm{L}$ of a $0.4 \mathrm{mg} / \mathrm{mL}$ solution of MTT in MEGM was added to each well, and the plate was incubated for an additional $4 \mathrm{~h}$. The MEGM/MTT mixture was aspirated and DMSO $(200 \mu \mathrm{L})$ was added to dissolve the resulting purple formazan crystals. The absorbance of the solutions in each well was read at $550 \mathrm{~nm}$. Absorbance values were normalized to DMSO-containing control wells and plotted as concentration of test compound versus \% cell viability. $\mathrm{IC}_{50}$ and $\mathrm{IC}_{20}$ values were interpolated from the resulting dose-dependent curves. $\mathrm{The}_{\mathrm{IC}}$ and $\mathrm{IC}_{20}$ values correspond to the concentration required to decrease cell viability by $50 \%$ or $20 \%$ and were calculated from dose-response curves. The reported $\mathrm{IC}_{50}$ values are the average of three independent experiments.

\subsection{Tumorsphere Formation and Viability Assay}

HMLER-shEcad cells $\left(5 \times 10^{3}\right)$ were plated in ultralow-attachment 96-well plates (Corning, New York, NY, USA) and incubated in MEGM supplemented with B27 (Invitrogen), 20 ng/mL EGF, and $4 \mu \mathrm{g} / \mathrm{mL}$ heparin (Sigma, Poole, UK) for 5 days. Studies were also conducted in the presence of 3 and tolfenamic acid $(0-66 \mu \mathrm{M})$. Mammospheres treated with 3 and tolfenamic acid (at their respective $\mathrm{IC}_{20}$ values, 5 days) were counted and imaged using an inverted microscope. The viability of the mammospheres was determined by addition of a resazurin-based reagent, TOX8 (Sigma). After incubation for $16 \mathrm{~h}$, the fluorescence of the solutions was read at $590 \mathrm{~nm}\left(\lambda_{\mathrm{ex}}=560 \mathrm{~nm}\right)$. Viable mammospheres reduce the amount of the oxidized TOX8 form (blue) and concurrently increases the amount of the fluorescent TOX8 intermediate (red), indicating the degree of mammosphere cytotoxicity caused by the test compound. Fluorescence values were normalized to DMSO-containing controls and plotted as concentration of test compound versus \% mammospheres viability. $\mathrm{IC}_{50}$ values were interpolated from the resulting dose-dependent curves (Figure $3 \mathrm{C}$ ). The $\mathrm{IC}_{50}$ values correspond to the concentration required to decrease mammosphere viability by $50 \%$ and were calculated from dose-response curves. Identical studies were also conducted in the presence of cobalt chloride $(5 \mu \mathrm{M})$. The reported $\mathrm{IC}_{50}$ values are the average of two independent experiments.

\subsection{Cellular Uptake}

To measure the cellular uptake of 3,1 million HMLER-shEcad cells were treated with $3(0.5 \mu \mathrm{M}$ for $16 \mathrm{~h})$. Then the media was removed, the cells were washed with PBS solution $(2 \mathrm{~mL} \times 3)$, harvested, and centrifuged. The cellular pellet was suspended in an appropriate volume of PBS to obtain a homogeneous cell suspension $(1 \mathrm{~mL})$. The suspension was divided into two. One part was used to determine the cobalt content in the whole cell and other was used for nuclear, cytoplasmic, and membrane analysis. The Thermo Scientific NE-PER Nuclear and Cytoplasmic Extraction Kit was 
used to extract and separate the nuclear, cytoplasmic, and membrane fractions. The fractions were dissolved in $65 \% \mathrm{HNO}_{3}$ overnight $(250 \mu \mathrm{L}$ final volume). The samples were then diluted 5-fold with water and analyzed using ICP-MS (PerkinElmer NexION 350D, Waltham, MA, USA). Cobalt levels are expressed as $\mathrm{Co}$ (ppb) per million cells. Results are presented as the mean of five determinations for each data point.

\subsection{Immunoblotting Analysis}

HMLER-shEcad cells $\left(5 \times 10^{5}\right.$ cells) were incubated with $3(0.125,0.25$, and $0.5 \mu \mathrm{M}), 2(20 \mu \mathrm{M})$, and tolfenamic acid $(20 \mu \mathrm{M})$ for $72 \mathrm{~h}$ at $37{ }^{\circ} \mathrm{C}$. Cells were washed with PBS, scraped into sodium dodecylsulfate polyacrylamide gel electrophoresis (SDS-PAGE) loading buffer (64 mM Tris- $\mathrm{HCl}$ ( $\mathrm{pH}$ 6.8)/9.6\% glycerol/2\% SDS/5\% $\beta$-mercaptoethanol/0.01\% bromophenol blue), and incubated at $95{ }^{\circ} \mathrm{C}$ for $10 \mathrm{~min}$. Whole cell lysates were resolved by $4 \%-20 \%$ SDS-PAGE (200 V for $25 \mathrm{~min}$ ) followed by electrotransfer to polyvinylidene difluoride membrane (PVDF, $350 \mathrm{~mA}$ for $1 \mathrm{~h}$ ). Membranes were blocked in 5\% (w/v) nonfat milk in PBST (PBS/0.1\% Tween 20) and incubated with the appropriate primary antibodies (Cell Signaling Technology, Danvers, MA, USA). After incubation with horseradish peroxidase-conjugated secondary antibodies (Cell Signaling Technology), immune complexes were detected with the electrochemiluminescence (ECL) detection reagent (BioRad, Hertfordshire, UK) and analyzed using a chemiluminescence imager (Amersham Imager 600, Tokyo, Japan).

\subsection{Flow Cytometry}

HMLER-shEcad cells were seeded in 6-well plates (at a density of $5 \times 10^{5}$ cells $/ \mathrm{mL}$ ) and the cells were allowed to attach overnight. The cells were treated with lipopolysaccharide (LPS) (5 $\mu \mathrm{M}$ for $24 \mathrm{~h})$, and then treated with $3(0.125$ and $0.5 \mu \mathrm{M})$ and incubated for a further $48 \mathrm{~h}$. The cells were then harvested by trypsinization, fixed with $4 \%$ paraformaldehyde (at $37^{\circ} \mathrm{C}$ for $10 \mathrm{~min}$ ), permeabilized with ice-cold methanol (for $30 \mathrm{~min})$, and suspended in PBS $(100 \mu \mathrm{L})$. The Alexa Fluor ${ }^{\circledR} 488$ nm-labeled anti-COX-2 antibody ( $2 \mu \mathrm{L})$ was then added to the cell suspension and incubated in the dark for $1 \mathrm{~h}$. The cells were then washed with PBS $(1 \mathrm{~mL})$ and analyzed using a FACSCanto II flow cytometer (BD Biosciences, San Jose, CA, USA). The FL1 channel was used to assess COX-2 expression. Cell populations were analyzed using the FlowJo software (Tree Star, Ashland, OR, USA).

Supplementary Materials: The following are available online at www.mdpi.com/2304-6740/5/1/12/s1, Figures S1-S13.

Acknowledgments: Kogularamanan Suntharalingam is supported by an Early Career Fellowship (ECF-2014-178) from the Leverhulme Trust. Arvin Eskandari received financial support from a King's College London Faculty Graduate School International Studentship. We are grateful to Robert Weinberg for providing the HMLER and HMLER-shEcad cell lines used in this study.

Author Contributions: Kogularamanan Suntharalingam conceived and designed the experiments; Paul B. Cressey and Arvin Eskandari performed the experiments; Kogularamanan Suntharalingam, Paul B. Cressey and Arvin Eskandari analyzed the data; Kogularamanan Suntharalingam and Paul B. Cressey wrote the paper.

Conflicts of Interest: The authors declare no conflict of interest.

\section{References}

1. World Health Organization. Fact Sheet; WHO Press: Geneva, Switzerland, 2015.

2. Morrison, R.; Schleicher, S.M.; Sun, Y.; Niermann, K.J.; Kim, S.; Spratt, D.E.; Chung, C.H.; Lu, B. Targeting the mechanisms of resistance to chemotherapy and radiotherapy with the cancer stem cell hypothesis. J. Oncol. 2011, 2011, 941876. [CrossRef] [PubMed]

3. Gupta, P.B.; Chaffer, C.L.; Weinberg, R.A. Cancer stem cells: Mirage or reality? Nat. Med. 2009, 15, 1010-1012. [CrossRef] [PubMed]

4. Nguyen, L.V.; Vanner, R.; Dirks, P.; Eaves, C.J. Cancer stem cells: An evolving concept. Nat. Rev. Cancer 2012, 12, 133-143. [CrossRef] [PubMed] 
5. Dean, M.; Fojo, T.; Bates, S. Tumour stem cells and drug resistance. Nat. Rev. Cancer 2005, 5, $275-284$. [CrossRef] [PubMed]

6. Tan, B.T.; Park, C.Y.; Ailles, L.E.; Weissman, I.L. The cancer stem cell hypothesis: A work in progress. Lab. Investig. 2006, 86, 1203-1207. [CrossRef] [PubMed]

7. Kaiser, J. The cancer stem cell gamble. Science 2015, 347, 226-229. [CrossRef] [PubMed]

8. Chen, K.; Huang, Y.-H.; Chen, J.-L. Understanding and targeting cancer stem cells: Therapeutic implications and challenges. Acta Pharmacol. Sin. 2013, 34, 732-740. [CrossRef] [PubMed]

9. Marx, J. Cancer's perpetual source? Science 2007, 317, 1029-1031. [CrossRef] [PubMed]

10. Yu, Y.; Ramena, G.; Elble, R.C. The role of cancer stem cells in relapse of solid tumors. Front. Biosci. 2012, 4, 1528-1541. [CrossRef]

11. Feng, Y.X.; Sokol, E.S.; Del Vecchio, C.A.; Sanduja, S.; Claessen, J.H.; Proia, T.A.; Jin, D.X.; Reinhardt, F.; Ploegh, H.L.; Wang, Q.; et al. Epithelial-to-mesenchymal transition activates PERK-eIF2 $\alpha$ and sensitizes cells to endoplasmic reticulum stress. Cancer Discov. 2014, 4, 702-715. [CrossRef] [PubMed]

12. Lamb, R.; Harrison, H.; Hulit, J.; Smith, D.L.; Lisanti, M.P.; Sotgia, F. Mitochondria as new therapeutic targets for eradicating cancer stem cells: Quantitative proteomics and functional validation via MCT1/2 inhibition. Oncotarget 2014, 5, 11029-11037. [CrossRef] [PubMed]

13. Al-Hajj, M.; Wicha, M.S.; Benito-Hernandez, A.; Morrison, S.J.; Clarke, M.F. Prospective identification of tumorigenic breast cancer cells. Proc. Natl. Acad. Sci. USA 2003, 100, 3983-3988. [CrossRef] [PubMed]

14. Eramo, A.; Lotti, F.; Sette, G.; Pilozzi, E.; Biffoni, M.; Di Virgilio, A.; Conticello, C.; Ruco, L.; Peschle, C.; De Maria, R. Identification and expansion of the tumorigenic lung cancer stem cell population. Cell Death Differ. 2008, 15, 504-514. [CrossRef] [PubMed]

15. Li, C.; Heidt, D.G.; Dalerba, P.; Burant, C.F.; Zhang, L.; Adsay, V.; Wicha, M.; Clarke, M.F.; Simeone, D.M. Identification of pancreatic cancer stem cells. Cancer Res. 2007, 67, 1030-1037. [CrossRef] [PubMed]

16. Prince, M.E.; Sivanandan, R.; Kaczorowski, A.; Wolf, G.T.; Kaplan, M.J.; Dalerba, P.; Weissman, I.L.; Clarke, M.F.; Ailles, L.E. Identification of a subpopulation of cells with cancer stem cell properties in head and neck squamous cell carcinoma. Proc. Natl. Acad. Sci. USA 2007, 104, 973-978. [CrossRef] [PubMed]

17. Singh, S.K.; Hawkins, C.; Clarke, I.D.; Squire, J.A.; Bayani, J.; Hide, T.; Henkelman, R.M.; Cusimano, M.D.; Dirks, P.B. Identification of human brain tumour initiating cells. Nature 2004, 432, 396-401. [CrossRef] [PubMed]

18. Janikova, M.; Skarda, J. Differentiation pathways in carcinogenesis and in chemo- and radioresistance. Neoplasma 2012, 59, 6-17. [CrossRef] [PubMed]

19. Korkaya, H.; Paulson, A.; Charafe-Jauffret, E.; Ginestier, C.; Brown, M.; Dutcher, J.; Clouthier, S.G.; Wicha, M.S. Regulation of mammary stem/progenitor cells by PTEN/Akt/ $\beta$-catenin signaling. PLoS Biol. 2009, 7, e1000121. [CrossRef] [PubMed]

20. Takebe, N.; Harris, P.J.; Warren, R.Q.; Ivy, S.P. Targeting cancer stem cells by inhibiting Wnt, Notch, and Hedgehog pathways. Nat. Rev. Clin. Oncol. 2011, 8, 97-106. [CrossRef] [PubMed]

21. Albini, A.; Bruno, A.; Gallo, C.; Pajardi, G.; Noonan, D.M.; Dallaglio, K. Cancer stem cells and the tumor microenvironment: Interplay in tumor heterogeneity. Connect. Tissue Res. 2015, 56, 414-425. [CrossRef] [PubMed]

22. Kise, K.; Kinugasa-Katayama, Y.; Takakura, N. Tumor microenvironment for cancer stem cells. Adv. Drug Deliv. Rev. 2015, 99, 197-205. [CrossRef] [PubMed]

23. Boodram, J.N.; McGregor, I.J.; Bruno, P.M.; Cressey, P.B.; Hemann, M.T.; Suntharalingam, K. Breast cancer stem cell potent copper(II)-non-steroidal anti-inflammatory drug complexes. Angew. Chem. Int. Ed. 2016, 55, 2845-2850. [CrossRef] [PubMed]

24. Cressey, P.B.; Eskandari, A.; Bruno, P.M.; Lu, C.; Hemann, M.T.; Suntharalingam, K. The potent inhibitory effect of a naproxen-appended cobalt(III)-cyclam complex on cancer stem cells. ChemBioChem 2016, 17, 1713-1718. [CrossRef] [PubMed]

25. Eskandari, A.; Boodram, J.N.; Cressey, P.B.; Lu, C.; Bruno, P.M.; Hemann, M.T.; Suntharalingam, K. The breast cancer stem cell potency of copper(II) complexes bearing nonsteroidal anti-inflammatory drugs and their encapsulation using polymeric nanoparticles. Dalton Trans. 2016, 45, 17867-17873. [CrossRef] [PubMed] 
26. Gonzalez-Bartulos, M.; Aceves-Luquero, C.; Qualai, J.; Cusso, O.; Martinez, M.A.; Fernandez de Mattos, S.; Menendez, J.A.; Villalonga, P.; Costas, M.; Ribas, X.; et al. Pro-oxidant activity of amine-pyridine-based iron complexes efficiently kills cancer and cancer stem-like cells. PLoS ONE 2015, 10, e0137800. [CrossRef] [PubMed]

27. Lum, C.T.; Wong, A.S.; Lin, M.C.; Che, C.M.; Sun, R.W. A gold(III) porphyrin complex as an anti-cancer candidate to inhibit growth of cancer-stem cells. Chem. Commun. 2013, 49, 4364-4366. [CrossRef] [PubMed]

28. Suntharalingam, K.; Lin, W.; Johnstone, T.C.; Bruno, P.M.; Zheng, Y.R.; Hemann, M.T.; Lippard, S.J. A breast cancer stem cell-selective, mammospheres-potent osmium(VI) nitrido complex. J. Am. Chem. Soc. 2014, 136, 14413-14416. [CrossRef] [PubMed]

29. Heddleston, J.M.; Li, Z.; Lathia, J.D.; Bao, S.; Hjelmeland, A.B.; Rich, J.N. Hypoxia inducible factors in cancer stem cells. Br. J. Cancer 2010, 102, 789-795. [CrossRef] [PubMed]

30. Heddleston, J.M.; Li, Z.; McLendon, R.E.; Hjelmeland, A.B.; Rich, J.N. The hypoxic microenvironment maintains glioblastoma stem cells and promotes reprogramming towards a cancer stem cell phenotype. Cell Cycle 2009, 8, 3274-3284. [CrossRef] [PubMed]

31. Li, Z.; Bao, S.; Wu, Q.; Wang, H.; Eyler, C.; Sathornsumetee, S.; Shi, Q.; Cao, Y.; Lathia, J.; McLendon, R.E.; et al. Hypoxia-inducible factors regulate tumorigenic capacity of glioma stem cells. Cancer Cell 2009, 15, 501-513. [CrossRef] [PubMed]

32. Soeda, A.; Park, M.; Lee, D.; Mintz, A.; Androutsellis-Theotokis, A.; McKay, R.D.; Engh, J.; Iwama, T.; Kunisada, T.; Kassam, A.B.; et al. Hypoxia promotes expansion of the CD133-positive glioma stem cells through activation of HIF-1 $\alpha$. Oncogene 2009, 28, 3949-3959. [CrossRef] [PubMed]

33. Zhang, J.; Li, L. Stem cell niche: Microenvironment and beyond. J. Biol. Chem. 2008, 283, 9499-9503. [CrossRef] [PubMed]

34. Abu-Surrah, A.S.; Kettunen, M. Platinum group antitumor chemistry: Design and development of new anticancer drugs complementary to cisplatin. Curr. Med. Chem. 2006, 13, 1337-1357. [CrossRef] [PubMed]

35. Hall, M.D.; Failes, T.W.; Yamamoto, N.; Hambley, T.W. Bioreductive activation and drug chaperoning in cobalt pharmaceuticals. Dalton Trans. 2007, 3983-3990. [CrossRef] [PubMed]

36. Heffern, M.C.; Yamamoto, N.; Holbrook, R.J.; Eckermann, A.L.; Meade, T.J. Cobalt derivatives as promising therapeutic agents. Curr. Opin. Chem. Biol. 2013, 17, 189-196. [CrossRef] [PubMed]

37. Munteanu, C.R.; Suntharalingam, K. Advances in cobalt complexes as anticancer agents. Dalton Trans. 2015, 44, 13796-13808. [CrossRef] [PubMed]

38. Chang, J.Y.; Lu, G.L.; Stevenson, R.J.; Brothers, P.J.; Clark, G.R.; Botting, K.J.; Ferry, D.M.; Tercel, M.; Wilson, W.R.; Denny, W.A.; et al. Cross-bridged cyclen or cyclam Co(III) complexes containing cytotoxic ligands as hypoxia-activated prodrugs. Inorg. Chem. 2013, 52, 7688-7698. [CrossRef] [PubMed]

39. Chang, J.Y.-C.; Stevenson, R.J.; Lu, G.-L.; Brothers, P.J.; Clark, G.R.; Denny, W.A.; Ware, D.C. Syntheses of 8-quinolinolatocobalt(III) complexes containing cyclen based auxiliary ligands as models for hypoxia-activated prodrugs. Dalton Trans. 2010, 39, 11535-11550. [CrossRef] [PubMed]

40. Renfrew, A.K.; Bryce, N.S.; Hambley, T. Cobalt(III) chaperone complexes of curcumin: Photoreduction, cellular accumulation and light-selective toxicity towards tumour cells. Chemistry 2015, 21, 15224-15234. [CrossRef] [PubMed]

41. Yamamoto, N.; Danos, S.; Bonnitcha, P.D.; Failes, T.W.; New, E.J.; Hambley, T.W. Cellular uptake and distribution of cobalt complexes of fluorescent ligands. J. Biol. Inorg. Chem. 2008, 13, 861-871. [CrossRef] [PubMed]

42. Yamamoto, N.; Renfrew, A.K.; Kim, B.J.; Bryce, N.S.; Hambley, T.W. Dual targeting of hypoxic and acidic tumor environments with a cobalt(III) chaperone complex. J. Med. Chem. 2012, 55, 11013-11021. [CrossRef] [PubMed]

43. Abramson, S.B.; Weissmann, G. The mechanisms of action of nonsteroidal antiinflammatory drugs. Arthritis Rheum. 1989, 32, 1-9. [CrossRef] [PubMed]

44. Moon, C.M.; Kwon, J.H.; Kim, J.S.; Oh, S.H.; Jin Lee, K.; Park, J.J.; Pil Hong, S.; Cheon, J.H.; Kim, T.I.; Kim, W.H. Nonsteroidal anti-inflammatory drugs suppress cancer stem cells via inhibiting PTGS2 (cyclooxygenase 2) and NOTCH/HES1 and activating PPARG in colorectal cancer. Int. J. Cancer 2014, 134, 519-529. [CrossRef] [PubMed]

45. Singh, B.; Berry, J.A.; Shoher, A.; Ramakrishnan, V.; Lucci, A. Cox-2 overexpression increases motility and invasion of breast cancer cells. Int. J. Oncol. 2005, 26, 1393-1399. [CrossRef] [PubMed] 
46. Sharma, V.; Dixit, D.; Ghosh, S.; Sen, E. Cox-2 regulates the proliferation of glioma stem like cells. Neurochem. Int. 2011, 59, 567-571. [CrossRef] [PubMed]

47. Pentikainen, P.J.; Neuvonen, P.J.; Backman, C. Human pharmacokinetics of tolfenamic acid, a new anti-inflammatory agent. Eur. J. Clin. Pharmacol. 1981, 19, 359-365. [CrossRef] [PubMed]

48. Meieranz, S.; Stefanopoulou, M.; Rubner, G.; Bensdorf, K.; Kubutat, D.; Sheldrick, W.S.; Gust, R. The biological activity of zeise's salt and its derivatives. Angew. Chem. Int. Ed. 2015, 54, 2834-2837. [CrossRef] [PubMed]

49. Ott, I.; Kircher, B.; Bagowski, C.P.; Vlecken, D.H.; Ott, E.B.; Will, J.; Bensdorf, K.; Sheldrick, W.S.; Gust, R. Modulation of the biological properties of aspirin by formation of a bioorganometallic derivative. Angew. Chem. Int. Ed. 2009, 48, 1160-1163. [CrossRef] [PubMed]

50. Pathak, R.K.; Marrache, S.; Choi, J.H.; Berding, T.B.; Dhar, S. The prodrug platin-A: Simultaneous release of cisplatin and aspirin. Angew. Chem. Int. Ed. 2014, 53, 1963-1967. [CrossRef] [PubMed]

51. Psomas, G.; Kessissoglou, D.P. Quinolones and non-steroidal anti-inflammatory drugs interacting with copper(II), nickel(II), cobalt(II) and zinc(II): Structural features, biological evaluation and perspectives. Dalton Trans. 2013, 42, 6252-6276. [CrossRef] [PubMed]

52. Krstic, N.S.; Nikolic, R.S.; Stankovic, M.N.; Nikolic, N.G.; Dordevic, D.M. Coordination compounds of M(II) biometal ions with acid-type anti-inflammatory drugs as ligands-A review. Trop. J. Pharm. Res. 2015, 14, 337-349. [CrossRef]

53. Banti, C.N.; Hadjikakou, S.K. Non-steroidal anti-inflammatory drugs (NSAIDS) in metal complexes and their effect at the cellular level. Eur. J. Inorg. Chem. 2016, 2016, 3048-3071. [CrossRef]

54. Dontu, G.; Abdallah, W.M.; Foley, J.M.; Jackson, K.W.; Clarke, M.F.; Kawamura, M.J.; Wicha, M.S. In vitro propagation and transcriptional profiling of human mammary stem/progenitor cells. Genes Dev. 2003, 17, 1253-1270. [CrossRef] [PubMed]

55. Roos, W.P.; Thomas, A.D.; Kaina, B. DNA damage and the balance between survival and death in cancer biology. Nat. Rev. Cancer 2016, 16, 20-33. [CrossRef] [PubMed]

56. Singh, B.; Cook, K.R.; Vincent, L.; Hall, C.S.; Martin, C.; Lucci, A. Role of Cox-2 in tumorospheres derived from a breast cancer cell line. J. Surg. Res. 2011, 168, e39-e49. [CrossRef] [PubMed]

57. Kanojia, D.; Zhou, W.; Zhang, J.; Jie, C.; Lo, P.K.; Wang, Q.; Chen, H. Proteomic profiling of cancer stem cells derived from primary tumors of HER2/Neu transgenic mice. Proteomics 2012, 12, 3407-3415. [CrossRef] [PubMed]

58. Bosnich, B.; Poon, C.K.; Tobe, M.L. Complexes of cobalt(III) with a cyclic tetradentate secondary amine. Inorg. Chem. 1965, 4, 1102-1108. [CrossRef]

59. Gupta, P.B.; Onder, T.T.; Jiang, G.; Tao, K.; Kuperwasser, C.; Weinberg, R.A.; Lander, E.S. Identification of selective inhibitors of cancer stem cells by high-throughput screening. Cell 2009, 138, 645-659. [CrossRef] [PubMed]

(C) 2017 by the authors; licensee MDPI, Basel, Switzerland. This article is an open access article distributed under the terms and conditions of the Creative Commons Attribution (CC BY) license (http:/ / creativecommons.org/licenses/by/4.0/). 